\title{
A Systematic Review of Self-monitoring Interventions in Promoting Physical Activity among Adolescents in South Asian Countries
}

\author{
Tengku Fadilah Tengku Kamalden*, Shashini Anushka Wickramarachchi, Soh Kim Geok, \\ Qais Gasibat
}

\author{
Department of Sport Studies, Universiti of Putra Malaysia (UPM), 43400 Serdang, Selangor, Malaysia
}

Received August 31, 2020; Revised October 12, 2020; Accepted November 11, 2020

\section{Cite This Paper in the following Citation Styles}

(a): [1] Tengku Fadilah Tengku Kamalden, Shashini Anushka Wickramarachchi, Soh Kim Geok, Qais Gasibat, "A Systematic Review of Self-monitoring Interventions in Promoting Physical Activity among Adolescents in South Asian Countries," International Journal of Human Movement and Sports Sciences, Vol. 8, No. 6, pp. 321 - 328, 2020. DOI: 10.13189/saj.2020.080603.

(b): Tengku Fadilah Tengku Kamalden, Shashini Anushka Wickramarachchi, Soh Kim Geok, Qais Gasibat (2020). A Systematic Review of Self-monitoring Interventions in Promoting Physical Activity among Adolescents in South Asian Countries. International Journal of Human Movement and Sports Sciences, 8(6), 321 - 328. DOI: 10.13189/saj.2020.080603.

Copyright $\bigcirc 2020$ by authors, all rights reserved. Authors agree that this article remains permanently open access under the terms of the Creative Commons Attribution License 4.0 International License

\begin{abstract}
The emphasis is on puberty, as this is a crucial period of the growth of becoming overweight and obese due to inadequate eating habits and physical inactivity. Lifestyle risk factors are not well known to the South Asian people. The purpose of this review is to determine whether self-monitoring physical activity (PA) programmes can be an effective tool to improve PA levels in school-age children and adolescents, hence be adopted to serve as a platform for additional research. Systematic search was conducted using PUBMED, MEDLINE and Google Scholar databases from Afghanistan, India, Pakistan, Nepal, Bangladesh, Sri Lanka, Bhutan, and the Maldives. The electronic search yielded an initial 70 articles and the majority of articles were eliminated. The remaining relevant papers were 18 that became the basis for this review. Review sources were from 2008 to 2019. The majority of South Asian adolescents were not active enough to meet the recommended guidelines for PA. Further, none of the articles were published under self-monitoring PA interventions among age 11 to 19 adolescents in South Asia. Further knowledge concerning Non-Communicable Disease (NCD) and healthy lifestyle factors were poor among school adolescents. The outcomes of this review highlight the need for evidence-based intervention programmes with the potential of self-monitoring to be incorporated into the national
\end{abstract}

education system.

Keywords Self-monitoring, Physical Activity, Adolescents, South Asia

\section{Introduction}

Self-monitoring is the proposition that individuals can and should exercise control over their expressive behaviour, self-presentation and nonverbal expression of emotion. Self-monitoring mechanisms greatly channel and shape the perceptions of the environment, attitudes in social contexts and the evolving dynamics of encounters with other people [29]. Research has suggested that it is necessary to track Physical Activity (PA) in order to avoid the risk factors associated with life-style behaviours. The practice of self-monitoring healthy behaviours in the lifestyle of a person has been shown to be reliably associated with greater weight loss. Although several intervention studies have shown the presence and self-monitoring of PA was part of the process, several research studies investigated dietary auto-monitoring in order to achieve weight loss goals [8].

Many studies have been undertaken in other countries 
through self-monitoring physical activities compared to Asian countries. According to Van Sluijs et al. [30] of the 33 studies of children performed in 2007, 18 were in the US, seven in the UK and the rest in other countries. Most prior research initiatives of children (82\%), of which 14 were community / family based, assessed school-related interventions.

Obesity is considered by the World Health Organization as "one of the world's most significant issues in the public health of the 21st century" [33]. PA is important to maintain health and well-being overall and to reduce obesity and non-communicable diseases. Among South Asians, the resistance to insulin and clustering of additional proatherogenic factors (metabolic syndrome) are major contributors to Type 2 diabetes as they undergo rapid demographic, dietary and economic shifts. As migration from city to city is on the rise, this inland migrant population is urbanised and mechanised which results in a nutritional deficiency, inactivity, stress and increased alcohol and tobacco consumption [20]. For example, in comparison to other developed and developing countries, the reduction in PA rates in Sri Lanka is less.

This research review focused on all research linked to PA self-monitoring in South Asian school children and adolescents to minimise non-communicable diseases. Persistently high levels of being overweight and obese during childhood and adulthood occurs globally, and the associated health complications have been well documented [19,24,31]. In high income countries, evidence from epidemiological studies has shown inconsistent relationships in the prevalence of obesity in immigrant South Asian children and adults compared with the native White populations [9]. However, the metabolic risks associated with obesity are greater for South Asian populations compared to White or other ethnic groups $[4,32]$. Given that levels of obesity in childhood are known to track into adulthood according to Lake et al. [18], then tackling obesity in South Asians is therefore a high priority for public health in terms of reducing ethnic inequalities [7].

According to the global strategy on diet, PA and health, PA guidelines concentrate on moderate to vigorous PA involving different aerobic exercises for at least 60 minutes a day to have a positive effect on the maintenance and growth of good cardio respiratory and metabolic functions in children and adolescents aged 5 to 17 years old [12]. It has been shown that moderate vagarious physical activities have a positive impact on the improvement of cardio metabolism, whereas low intensity behaviours do not appear to be as effective or consistent [14]. Obesity caused by excess calories / energy consumption has impacts on health and increased risks in childhood as well as in later life for diseases such as Type 2 diabetes, cardiovascular conditions, hypertension and polycystic ovarian disease.

\section{Materials and Methods}

Data on self-monitoring PA programmes concerning the prevalence of non-communicable diseases among adolescents across the South Asian countries was obtained from several sources. Relevant articles were identified by a computerised search in PUBMED, MEDLINE and Google Scholar databases. Individualised search strategies for the different data bases included a combination of the following keywords: "self-monitoring, obesity, PA, adolescents, South Asia". Thirty (30) papers from South Asian countries were discovered and fourteen (14) were included in the evaluation. A further four (04) readings were included in the evaluation from the forty (40) papers which were based on randomised controlled trials (Figure 1: Data Collection Flow Chart).

The small amount of research that has been published on this important public health issue shows that research into self-monitoring PA programmes to promote health statues in adolescents in South Asia is still at a poor level.

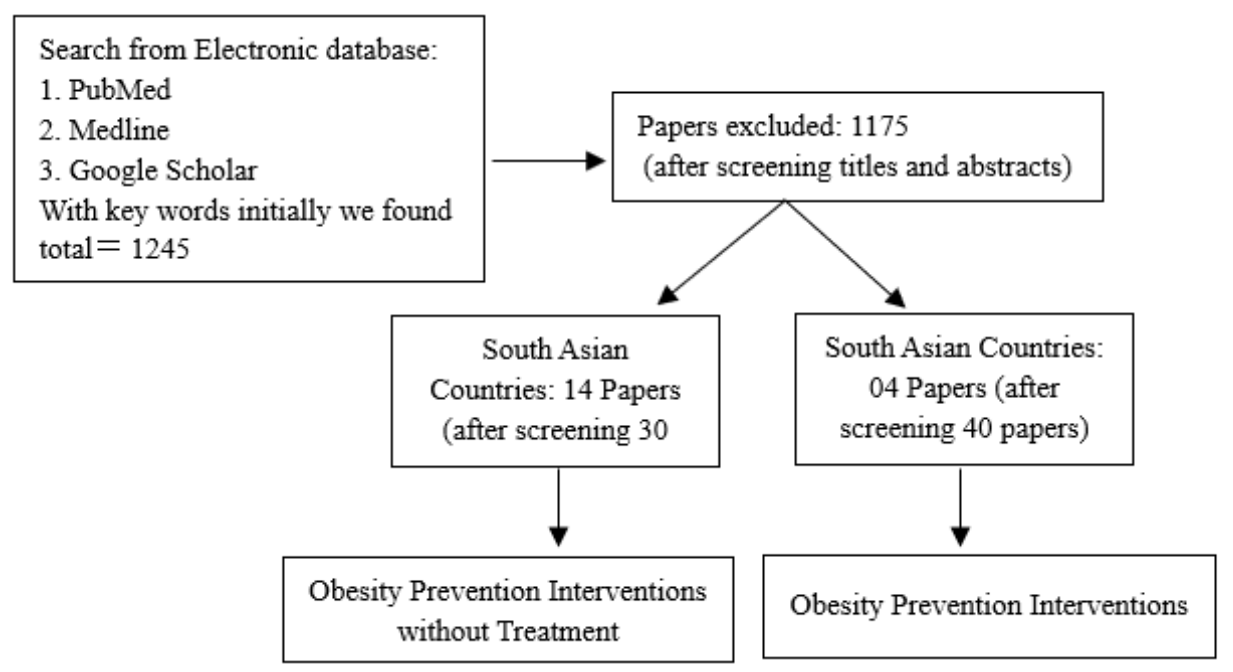

Figure 1. Data Collection Flow Chart 


\subsection{Selection of Literature (Inclusion and Exclusion Criteria)}

This study focused on self-monitoring training interventions for PA, carried out without diagnosis or medication, to reduce obesity in children and their origin and to avoid obesity in such children. Inclusion studies were eligible if: Primary or secondary findings were overweight or obese or related risk for obese while undertaking measures for PA. South-Asian children aged between 11 and 19 years (health promotion / education programmes) engaged in obesity-related programmes were selected. The study focused on all aspects of obesity, such as the cause, medical implications, nutrition and development. Studies were omitted if they were not conducted between 2008 and 2019.

This analysis was limited to studies at the national level or reports on large, sub-national population data from regions that were representative of the population. Further estimates of the PA were provided in the original report of the source.

\section{Results}

Study outcomes of PA interventions that were conducted in South Asia are summarised in Table 1. This indicates the age categories used for the interventions, the assessed variables, time framework, results and the references of the studies.

Table 1. Summary of PA level and lifestyle associated risk factors in South Asia: PA Interventions

\begin{tabular}{|c|c|c|c|c|}
\hline $\begin{array}{l}\text { Sample } \\
\text { Size }\end{array}$ & Physical Activity & \multicolumn{2}{|c|}{ Results } & Reference \\
\hline \multirow{5}{*}{$(\mathrm{N}=634)$} & \multirow{5}{*}{$\begin{array}{l}\text { Knowledge of NCD } \\
\text { Health diet consumed } \\
\text { Engaged in adequate PA } \\
\text { Current Smokers } \\
\text { Current Alcohol }\end{array}$} & Knowledge of NCD & $43 \%$ & \multirow{5}{*}{$\begin{array}{c}\text { Gamage \& } \\
\text { Jayawardana, [10] }\end{array}$} \\
\hline & & Health diet consumed & $43 \%$ & \\
\hline & & Engaged in adequate PA & $20 \%$ & \\
\hline & & Current Smokers & $03 \%$ & \\
\hline & & Current Alcohol & $12 \%$ & \\
\hline \multirow{10}{*}{$(\mathrm{N}=176)$} & \multirow{10}{*}{$\begin{array}{l}\text { PA Level } \\
\text { Watching Video } \\
\text { Watching TV } \\
\text { Doing Homework }>2 \mathrm{~h} \\
\text { Consuming Meat } \\
\text { Fish or Other Food } \\
\text { Fast Food } \\
\text { Carbonated Drinks } \\
\text { Sweet Cookies } \\
\text { Vegetables and Fruits }\end{array}$} & PA Level & $1.6^{*}$ & \multirow{10}{*}{$\begin{array}{c}\text { Godakanda et al. } \\
{[11]}\end{array}$} \\
\hline & & Watching Video & $3.1 *$ & \\
\hline & & Watching TV & $2.6^{*}$ & \\
\hline & & Doing Homework >2h & $1.8^{*}$ & \\
\hline & & Consuming Meat & $1.9^{*}$ & \\
\hline & & Fish or Other Food & $1.6^{*}$ & \\
\hline & & Fast Food & $1.9 *$ & \\
\hline & & Carbonated Drinks & $1.9^{*}$ & \\
\hline & & Sweet Cookies & $1.8 *$ & \\
\hline & & Vegetables and Fruits & $0.6^{*}$ & \\
\hline \multirow{7}{*}{$(\mathrm{N}=360)$} & \multirow{2}{*}{$\begin{array}{c}\text { Sociographic Data } \\
\text { Rate of PA }\end{array}$} & \multicolumn{2}{|c|}{ Sociographic Data } & \multirow{7}{*}{ (Böhm et al. [6] } \\
\hline & & Rate of I & & \\
\hline & \multirow{5}{*}{$\begin{array}{l}20 \text { m Shuttle Run Test } \\
\text { Curl up Test, Push Ups } \\
\text { Sit \& Reach } \\
\text { Bioelectrical Impedance } \\
\text { Anthropometric Measures }\end{array}$} & \multicolumn{2}{|c|}{ Cardiovascular Endurance } & \\
\hline & & \multicolumn{2}{|c|}{ Muscular Strength \&Endurance } & \\
\hline & & \multicolumn{2}{|c|}{ Muscular Flexibility } & \\
\hline & & \multicolumn{2}{|c|}{ Body Composition } & \\
\hline & & \multicolumn{2}{|c|}{ Height \& weight } & \\
\hline$(\mathrm{N}=116)$ & $\begin{array}{l}\text { Waist circumference, BMI, } \\
\text { body composition, PA level, } \\
\text { sedentary activities, } \\
\text { cardiovascular fitness, and } \\
\text { self esteem }\end{array}$ & \multicolumn{2}{|c|}{$\begin{array}{l}\text { The waist circumference }(-0.37 ; \mathrm{P}<.0001) \text { and BMI }(-0.24 ; \mathrm{P} \\
<0.0001) \text { in relation to the control groups was } 6 \text { months before the } \\
\text { programme intervention and control group. Significant variations } \\
\text { between cardiovascular fitness, physical exercise, sedentary habits } \\
\text { and self-esteem were also observed. The overall enrolment in the } \\
\text { MEND programme was } 86 \% \text {. At } 12 \text { months, children in the } \\
\text { intervening community lowered their waist, BMI, and cardiovascular } \\
\text { fitness, PA and self-esteem by } 0,47(\mathrm{P}<0.0001) \text {, respectively, and } \\
0,23 \text {. (P<0.0001). }\end{array}$} & Sacher et al. [28] \\
\hline
\end{tabular}


Table 1 Continued

\begin{tabular}{|c|c|c|c|}
\hline$(\mathrm{N}=1814)$ & $\begin{array}{l}\text { Body mass index, } \\
\text { self-reported breakfast } \\
\text { consumption, diet and PA } \\
\text { related behaviours, and } \\
\text { psychosocial factors }\end{array}$ & $\begin{array}{l}\text { Public school students eat breakfast every day in contrast with private } \\
\text { school pupils (higher SES) }(73.8 \% \text { vs. } 66.3 \% \text {; }<0.01) \text {. More } 8 \text { th } \\
\text { graders eat daily breakfast compared to } 10 \text { th graders }(72.3 \% \text { vs } \\
67.0 \% \text { p }<0.05) \text {. The dose-response ratios of adolescents who } \\
\text { consumed breakfast everyday }(14.6 \%) \text { were found to be slightly } \\
\text { lower than those who consumed breakfast either occasionally } \\
(15.2 \%) \text { or never }(22.9 \%)(\mathrm{p}<0.05 \% \text { for trend). The boys }(15.4 \% \text { vs. } \\
16.5 \% \text { versus } 26.0 \% ; \mathrm{p}<0.05 \text { per person for trend) had a statistically } \\
\text { relevant relationship but not children. }\end{array}$ & Gupta et al. [12] \\
\hline$(\mathrm{N}=280)$ & $\begin{array}{l}\text { Blood Pressure (BP) Body } \\
\text { Mass Index (BMI) }\end{array}$ & $\begin{array}{l}\text { The mean difference between intervention and control measures was } \\
1.9 \mathrm{~mm} \mathrm{Hg}, 0.7 \mathrm{~mm} \mathrm{Hg} \text {, and } 0.55 \mathrm{~kg} / \mathrm{m} 2 \text { from baseline to following in } \\
\text { SBP, DBP and BMI ranking. }\end{array}$ & Alma et al. [1] \\
\hline$(\mathrm{N}=21)$ & $\begin{array}{l}\text { Body weight and height Body } \\
\text { composition } \\
\text { Blood samples }\end{array}$ & $\begin{array}{l}\text { The fibrinogen FSR }(\mathrm{P}=0.002) \text { was higher in the obese population } \\
\text { (vs. lean) and decreased following intervention }(\mathrm{P}=0.001) \text {. Upon } \\
\text { action, high concentrations of D-dimers were reduced }(\mathrm{P}=0.001) \text {, } \\
\text { though fibrinolysis was not enhanced. }\end{array}$ & $\begin{array}{c}\text { Balagopal et al. } \\
\text { [3] }\end{array}$ \\
\hline$(\mathrm{N}=6210)$ & $\begin{array}{l}\text { Knowledge of health, } \\
\text { nutrition, PA, } \\
\text { non-communicable diseases } \\
\text { and healthy cooking practices }\end{array}$ & $\begin{array}{l}\text { In } 75 \text { to } 94 \% \text { of the government and } 48 \text { to } 78 \% \text { of private school } \\
\text { students, all age ranges recorded poor baseline awareness and } \\
\text { behaviour ratings. A limited number of government school children } \\
\text { answered correctly with proteins ( } 14 \text { to } 17 \%) \text {, carbohydrates ( } 25 \text { to } \\
27 \% \text { ) and saturated fats ( } 18 \text { to } 32 \%) \text {. Children, parents and teachers } \\
\text { from private schools performed significantly better than public } \\
\text { schools }(\mathrm{P}, 0 \cdot 05) \text {. In all children, irrespective of the type of school, } \\
\text { scores improved after the intervention (P,0.001). }\end{array}$ & Shah et al. [26] \\
\hline$(\mathrm{N}=201)$ & $\begin{array}{l}\text { Changes in nutrition-related } \\
\text { knowledge, attitude, lifestyle } \\
\text { practices, food frequency and } \\
\text { body image }\end{array}$ & $\begin{array}{l}\text { The multicomponent diet and lifestyle model have succeeded in } \\
\text { enhancing dietary awareness, eating habits and lifestyle behaviours } \\
\text { and contributed to positive improvements in the anthropometric and } \\
\text { biochemical profiles of Asian Indian adolescents. This approach will } \\
\text { be used nationally for the prevention of obesity and diabetes. }\end{array}$ & (Singhal et al. [27] \\
\hline$(\mathrm{N}=1860)$ & $\begin{array}{c}\text { BMI, demographic } \\
\text { information (gender, date of } \\
\text { birth, residential address and } \\
\text { parental education), } \\
\text { family-based characteristics } \\
\text { (parental working status, } \\
\text { number of siblings and } \\
\text { number of persons in living } \\
\text { room of child), dietary } \\
\text { behaviours (breakfast, lunch, } \\
\text { family supper and fast food } \\
\text { and snacks), PA, and } \\
\text { sedentary lifestyle } \\
\end{array}$ & $\begin{array}{l}\text { Dietary, PA and sedentary lifestyles among Pakistani primary school } \\
\text { children are independent predictors of BMI overweight and higher and } \\
\text { are significantly affected by the socio-demographic features of the } \\
\text { population. This result reinforced the urgent need for a national diet } \\
\text { and PA policy and cultural engagement in poor-resource developing } \\
\text { countries. }\end{array}$ & $\begin{array}{c}\text { (Mushtaq et al. } \\
\text { [21] }\end{array}$ \\
\hline$(\mathrm{N}=610)$ & $\begin{array}{l}\text { Obesity, PA, excessive eating } \\
\text { of sweets, carbohydrate foods } \\
\text { and chocolate intake and } \\
\text { prolonged TV viewing }\end{array}$ & $\begin{array}{l}\text { In six months, the way children live was dramatically modified with } \\
\text { regards to obesity, excessive intake of food, excess candy and } \\
\text { chocolate, PA, and extended television watching. Reducing obesity } \\
\text { and altering the habits of children, as Public initiatives, can help to } \\
\text { reduce or decrease the diabetes epidemic. In particular, the first } \\
\text { fruitful steps in this direction will be a curriculum at the school level } \\
\text { that integrates the therapeutic interventions with the nutrition } \\
\text { programmes. }\end{array}$ & $\begin{array}{l}\text { Kameswararaom } \\
\text { \& Bachu [15] }\end{array}$ \\
\hline$(\mathrm{N}=1675)$ & $\begin{array}{l}\text { BMI, PA Level, Nutrition } \\
\text { Level }\end{array}$ & $\begin{array}{l}\text { The study highlights problems of Pakistani school children. } \\
\text { Notwithstanding a persistently high nutritional burden, there has been } \\
\text { a substantial rise in overweight and obese children. The emphasis on } \\
\text { childhood obesity prevention must include PA promotion strategies }\end{array}$ & Jafar et al. [13] \\
\hline$(\mathrm{N}=198)$ & $\begin{array}{l}\text { Demographic information } \\
\text { and the exposure of the } \\
\text { respondents to different risk } \\
\text { factors, such as routine PA at } \\
\text { home and at school, computer } \\
\text { and television hours, maternal } \\
\text { education and the weight and } \\
\text { height of parents. }\end{array}$ & $\begin{array}{l}\text { This study demonstrated that overweight and suffering from obesity } \\
\text { among urban school children in Dhaka, Bangladesh, was related to } \\
\text { several risks such as overweight parents, minimal physical exercise at } \\
\text { home and a high level of sedentary activity. Public health campaigns, } \\
\text { in order to minimise the potential burden of chronic obesity-related } \\
\text { disorders, are needed to encourage understanding of these risk factors } \\
\text { among children and youths. Schools should be the focus for children } \\
\text { and youths in various environments, as it provides important } \\
\text { prevention opportunities. }\end{array}$ & Bhuiyan et al. [5] \\
\hline
\end{tabular}


Table 1 Continued

\begin{tabular}{|c|c|c|c|}
\hline$(\mathrm{N}=398)$ & BMI, 24 hour diet recall & $\begin{array}{l}\text { While these figures reflect a small proportion of the population, } \\
\text { obesity and being overweight are high respectively, i.e. } 6 \% \text { and } 19 \% \text {. } \\
\text { In contrast to a mixed healthy diet, the children of wealthier schools } \\
\text { eat more junk food and have an imbalanced diet, with the majority of } \\
\text { them being sedentary, as the newspapers, the internet and indoor } \\
\text { sports (play stations etc.) have changed our lifestyle in the last ten } \\
\text { years. The general public, especially parents, should be aware of the } \\
\text { situation and participate in the activities of their children. Physical } \\
\text { education should be promoted and included in the curriculum physical } \\
\text { education }\end{array}$ & Aziz et al. [2] \\
\hline$(\mathrm{N}=979)$ & $\begin{array}{c}\text { BMI, Body Fat, Blood } \\
\text { Pressure }\end{array}$ & $\begin{array}{l}\text { In the sample population, there was a heavy prevalence of people } \\
\text { overweight / obese and suffering from hypertension. The high burden } \\
\text { of the issue, together with all its associated risks for the vulnerable } \\
\text { community, will serve as an opportunity for more study and a national } \\
\text { policy structure to reduce non-communicable disease risk. }\end{array}$ & $\begin{array}{c}\text { Kar \& } \\
\text { Khandelwal [16] }\end{array}$ \\
\hline$(\mathrm{N}=21)$ & BMI & $\begin{array}{l}\text { This research has shown that Bangladesh has a significant literary gap } \\
\text { concerning obesity / overweightness in children and adolescents. } \\
\text { While obesity amongst young people is generally still not seen as a } \\
\text { significant public health problem in Bangladesh, in some groups, } \\
\text { especially in urban children from affluent families, it is alarmingly } \\
\text { high and on the rise. The problem could be solved as soon as possible } \\
\text { through the recognition of high-risk groups and the implementation of } \\
\text { effective strategies to avoid further increase in overweight and } \\
\text { obesity. In turn, the prevalence of metabolic syndrome may play a } \\
\text { crucial role in reducing later-life socio-economic and public health } \\
\text { burdens. This can have a potential effect to incorporate educational } \\
\text { campaigns, which could be applied to the national level to facilitate } \\
\text { PA and safe eating habits. Additionally, large-scale prospective } \\
\text { studies are needed to improve comparability and predictability of } \\
\text { future patterns based on the context-specific concepts and obesity } \\
\text { reference criteria in the South Asian population. }\end{array}$ & $\begin{array}{c}\text { (Rahman et al. } \\
\text { [23] }\end{array}$ \\
\hline$(\mathrm{N}=449)$ & BMI, Socio-economic statues & $\begin{array}{l}\text { Research undoubtedly calls attention to the high prevalence of rural } \\
\text { childhood overweight and obese. Aggressive steps to avoid and } \\
\text { control obesity in children are the most effective method for } \\
\text { preventing and complicating obesity in adults. The development of } \\
\text { school education and therapy services by parents to bring about } \\
\text { meaningful dietary and lifestyle improvements for children could also } \\
\text { be a successful strategy to decelerate the growth in overweight and } \\
\text { obese children. }\end{array}$ & $\begin{array}{c}\text { (Kurlekar et al. } \\
\text { [17] }\end{array}$ \\
\hline$(\mathrm{N}=2189)$ & $\begin{array}{l}\text { BMI, PA level, indoor } \\
\text { activities such as TV } \\
\text { watching, computer } \\
\text { and video game, indoor } \\
\text { games, sleeping and long } \\
\text { school hours }\end{array}$ & $\begin{array}{l}\text { The findings indicate that in Mysore the prevalence of childhood } \\
\text { obesity is not as high as that of other research. Nevertheless, } \\
\text { overweightness and obesity were higher in urban areas than in rural } \\
\text { areas. In comparison to both city and rural children, the prevalence of } \\
\text { obesity and being overweight was observed much more in girls. This } \\
\text { then requires concerted action and the development of an awareness } \\
\text { campaign in schools and parents in order to engage in physical fitness, } \\
\text { sports and outdoor activities so as to stop the march towards obesity. }\end{array}$ & $\begin{array}{c}\text { (Saraswathi et al. } \\
{[26]}\end{array}$ \\
\hline
\end{tabular}

\section{Discussion}

To the knowledge of the authors, this is the first review that has identified research into self-monitoring PA interventions to promote PA among adolescents in South Asia. At the same time this report describes the common characteristics of South Asian studies conducted to prevent childhood obesity and the quality of evidence-based data from successful interventions. According to the findings all the interventions were undertaken to assess the PA level, obesity, socio demographic factors associated with inactivity, food patterns, dietary intakes and lifestyles of children and adolescents. Hence, there is no evidence supporting self-monitoring PA interventions. Therefore, researchers should do a greater amount of studies on self-monitoring PA intervention. This review reported 19 studies which were undertaken as interventions to evaluate PA in children and adolescents in South Asia.

A study by Gamage \& Jayawardana [10] showed that the knowledge of young students and their way of life in non-communicable disease areas and primary prevention was insufficient. This emphasises the importance of developing and implementing awareness-raising programmes within this population to build a framework for non-communicable disease risk surveillance. Quick action is nevertheless necessary, if the aforementioned goal is to be accomplished by children in order to combat 
the growing disease epidemic. Godakanda et al. [11] found that watching television at a rate of up to 2 hours a day and watching video / DVD for a time of up to two hours a day are risk factors for being overweight. However, the combination of total sedentary time (more sedentary) spending 4 hours and being overweight could not be found. The study revealed that total sedentary time was a risk factor for being overweight/obesity [25].

Böhm et al. [6] emphasised an evidence-based intervention programme with the potential to be incorporated into the national education system thus promoting health and well-being of adolescents in Sri Lanka to reduce obesity and physical inactivity. A study by Sacher et al. [28] showed the growing issue of obesity in children is a promising research topic. Further research is underway on the basis of methods that address the limits of the present trial, to assess the effectiveness of the programme on a greater scale. Gupta et al. [12] also found major problem for obesity that need to be dealt with urgently. This is because obesity in children leads to numerous medical and psychosocial issues (hypertension, Type 2 diabetes mellitus, Metabolism and hypercholesterolemia) in children. The most important approaches to combat childhood obesity are the improvements in behavioural behaviours and daily PA by parental initiatives. In pre-school adolescents, the high prevalence of overweight and obesity highlights the need for successful measures to reverse predicted patterns, beginning early in childhood.

The results of a study by Almas et al. [1] indicated that a school-based PA programme in a public sector girl's school of urban Pakistan would be feasible to prevent obesity and children being overweight. Balagopal et al. [3] displayed an important role in regulation and reduction in childhood PA for the Fractional Fibrinogen Synthesis Rate (FSR). Furthermore, the congruent reduction of fibrinogen FSR and the fibrinogen and D-dimer concentrations amid depressed fibrinolysis may have a positive effect on the coagulation system through intervention. Also, current data provides a strong case for future trials not only in order to address the ability, along with other pharmacological treatments, of different doses and training protocols to alter the apparent higher thrombotic potential of obese children, but also in order to further address the potential difference between the regulation of risk factors in children and senescence.

A study by Mushtaq et al. [12] focused on dietary behaviour and discovered that PA and the sedentary lifestyle of children in Pakistan who were overweight, obese, and with higher body mass indexes and socio-demographic associations among primary school children. In contrast with the children who regularly had breakfast, children who skipped their breakfast were more likely to be overweight and obese. Different breakfast patterns and prevalence of excessive weight revealed that the relationship of girls, but not boys, was significant.
However, children who had lunch at school and did not eat dinner with their families were identified with a higher risk of being too weighty. PA has an important, independent reverse relation to being overweight and with a high body weight index more than twice a week. Sedentary lifestyle including TV, computer work and video games has been shown to be a significantly independent link with a greater body mass index and risk of being overweight.

Reducing obesity and changes in the lifestyles of children as community programmes may delay or reduce the diabetes epidemic. In particular, the first successful steps in that direction are the school-level educational interventions which combine both behavioural and nutritional programmes [15]. According to a study by Jafar et al. [13] it would appear that the amount of children who are overweight or obese increases with age. Therefore, that study highlighted a unique challenge for Pakistan to deal with a rapid increase in the number of children suffering from over nutrition when the burden of under nutrition also persists in Pakistan. The possible risks of children being overweight or suffering from obesity are high when a child has an overweight parent and has been participating in sedentary behaviours, including TV and video games for more than 4 hours a day, while daily home activity appeared to be a defence. Children who spend more time in PA, for instance in overall outdoor games, were found to be at less at risk of being overweight or obese [5].

Findings by Aziz et al. [2] showed that the total calorie intake per day in two groups of different ages was greater than the usual range recommended but carbohydrate, fat and protein consumption was unequal, in comparison with the recommended pyramid for the food guide. A trend towards decreased PA was also observed because of sedentary lifestyles. As the children grow older, parenting and advice decreased. This sedentary lifestyle contributes significantly to childhood obesity within the wealthy paediatric community. It was revealed that there was a higher prevalence of obesity and excess overweight amongst boys than girls. A major cause for concern was the increased incidence of prehypertension and hypertension in overweight and obese children in contrast to their non-overweight counterparts. All obese and overweight indicators were positively associated with lower physical and socioeconomic activity [16].

There is a significant discrepancy in the literature concerning Bangladesh in terms of childhood and obesity / being overweight among adolescents. While young age obesity is generally not considered a serious public health problem in Bangladesh, the level of obesity in some groups, particularly among urban children in affluent families, is alarmingly high and increasing. The earliest possible solution to the problem would be to identify high-risk groups and design sustainable interventions to avoid further growth in children being overweight and 
obese. In order to avoid the socio-economic or public health burden in future lives, the prevalence of the metabolic syndrome among them could play a vital role. This could have a potential effect by introducing interventions focused on schools that can apply to community levels to promote safe PA and eating behaviours [23].

Boys were more likely to be overweight and obese than girls. The potential social explanations for this finding in a rural community may be that boys are motivated to have access to caloric-dense food, to tolerate sedentary habits and to have less physical stress. With higher maternal education, the proportion of overweight and obese children has increased [17].

The best way to track PA for the reduction of risk factors for teenagers in terms of lifestyle is by self-monitoring. However further work needs to be conducted on childhood obesity with system-based strategies and multiple interventions in different settings. Also illustrated was the successful implementation of neighbourhood health services with an emphasis on both nutrition and PA. Most current research has centred on urban areas in rural areas in South Asia and has found disparities in childhood obesity analysis. This review reveals that the relationship between childhood obesity and urban lifestyles has increased PA with sedentary living and unhealthy saturated fats, sugary processed food at school and at home. Therefore, studies comparing rural and urban young people are important.

\section{Conclusion}

The physical activity level, knowledge and lifestyle practices of adolescent students concerning non-communicable diseases and their primary prevention were found to be unsatisfactory. A sedentary lifestyle is recognised as a major risk factor for obesity and cardiovascular disease. The prevalence of children and adolescents being overweight and obese is a major public health concern, and weight related health problems are being diagnosed earlier in children and adolescents who are not exposed to confidence-building opportunities in their physical abilities early in life and who tend to be less active later in life. Movement skills such as running, jumping, and throwing can serve as the building blocks for a lifetime of physical activity. Children who do not develop these skills early in life may be less likely to meet or exceed recommendations for daily physical activity later in life.

\section{Acknowledgements}

The advice and guidance given by Dr QAIS GASIBAT has been of great help in drafting and writing this manuscript. The author also wishes to acknowledge the help of all the co-authors for the great ideas and recommendations to complete the writing process.

\section{Conflicts of Interest}

The authors declare that there is no conflict of interest regarding the publication of this paper.

\section{REFERENCES}

[1] Almas A, Islam M, Jafar TH. School-based physical activity programme in preadolescent girls (9-11) feasibility trial in Karachi, Pakistan. Archives of disease in childhood. 1;98(7),515-9, 2013

[2] Aziz S, Noorulain W, Zaidi UR, Hossain K, Siddiqui IA. Prevalence of overweight and obesity among children and adolescents of affluent schools in Karachi. JPMA. The Journal of the Pakistan Medical Association. 59(1), 35, 2009.

[3] Balagopal P, George D, Sweeten S, Mann KJ, Yarandi H, Mauras N, Vaughan DE. Response of fractional synthesis rate (FSR) of fibrinogen, concentration of D - dimer and fibrinolytic balance to physical activity - based intervention in obese children. Journal of Thrombosis and Haemostasis. 6(8),1296-303,2008.

[4] Bhopal R, Unwin N, White M, Yallop J, Walker L, Alberti KG, Harland J, Patel S, Ahmad N, Turner C, Watson B. Heterogeneity of coronary heart disease risk factors in Indian, Pakistani, Bangladeshi, and European origin populations: cross sectional study. Bmj. 24; 319(7204), 215-20, 1999

[5] Bhuiyan MU, Zaman S, Ahmed T. Risk factors associated with overweight and obesity among urban school children and adolescents in Bangladesh: a case-control study. BMC pediatrics. 13(1), 16,2013 .

[6] Böhm B, Karwiese SD, Böhm H, Oberhoffer R. Effects of mobile health including wearable activity trackers to increase physical activity outcomes among healthy children and adolescents: systematic review. JMIR mHealth and Health.;7(4), e8298,2009.

[7] Brown T, Smith S, Bhopal R, Kasim A, Summerbell C. Diet and physical activity interventions to prevent or treat obesity in South Asian children and adults: a systematic review and meta-analysis. International journal of environmental research and public health.. 12(1), 566-94.2015.

[8] Conroy MB, Yang K, Elci OU, Gabriel KP, Styn MA, Wang J, Kriska AM, Sereika SM, Burke LE. Physical activity self-monitoring and weight loss: 6-month results of the SMART trial. Medicine and science in sports and exercise. 43(8), 1568, 2011.

[9] El-Sayed AM, Scarborough P, Galea S. Ethnic inequalities in obesity among children and adults in the UK: a systematic review of the literature. Obesity Reviews. 12(5), e516-34, 2011.

[10] Gamage AU, Jayawardana PL. Knowledge of 
non-communicable diseases and practices related to healthy lifestyles among adolescents, in state schools of a selected educational division in Sri Lanka. BMC public health. 18(1), 64, 2018.

[11] Godakanda I, Abeysena C, Lokubalasooriya A. Sedentary behavior during leisure time, physical activity and dietary habits as risk factors of overweight among school children aged 14-15 years: case control study. BMC research notes. 1; 11(1), 186, 2018.

[12] Gupta N, Goel K, Shah P, Misra A. Childhood obesity in developing countries: epidemiology, determinants, and prevention. Endocrine reviews. 1;33(1),48-70,2012.

[13] Jafar TH, Qadri Z, Islam M, Hatcher J, Bhutta ZA, Chaturvedi N. Rise in childhood obesity with persistently high rates of undernutrition among urban school-aged Indo-Asian children. Archives of disease in childhood. 1; 93(5), 373-8, 2008.

[14] Janssen I, LeBlanc AG. Systematic review of the health benefits of physical activity and fitness in school-aged children and youth. International journal of behavioral nutrition and physical activity. Dec 1; 7(1): 40, 2010.

[15] Kameswararao AA, Bachu A. Survey of childhood diabetes and impact of school level educational interventions in rural schools in Karimnagar district. International Journal of Diabetes in Developing Countries. 29(2), 69, 2009.

[16] Kar S, Khandelwal B. Fast foods and physical inactivity are risk factors for obesity and hypertension among adolescent school children in east district of Sikkim, India. Journal of natural science, biology, and medicine. 6(2), 356, 2015.

[17] Kurlekar U, Oka G, Khare A. Prevalence of childhood overweight and obesity in rural Pune. Indian Journal of Child Health. 25; 3(4), 301-4, 2016.

[18] Lake JK, Power C, Cole TJ. Child to adult body mass index in the 1958 British birth cohort: associations with parental obesity. Archives of disease in childhood. 1; 77(5), 376-80. 1997.

[19] Lobstein T, Baur L, Uauy R. Obesity in children and young people: a crisis in public health. Obesity reviews. 5:4-85, 2004.

[20] Misra A, Bhardwaj S. Obesity and the metabolic syndrome in developing countries: focus on South Asians. In International Nutrition: Achieving Millennium Goals and Beyond (Vol. 78, pp. 133-140). Karger Publishers, 2014.

[21] Mushtaq MU, Gull S, Mushtaq K, Shahid U, Shad MA, Akram J. Dietary behaviors, physical activity and sedentary lifestyle associated with overweight and obesity, and their socio-demographic correlates, among Pakistani primary school children. International Journal of Behavioral Nutrition and Physical Activity. 1; 8(1), 130, 2011.

[22] Prochaska JJ, Sallis JF. A randomized controlled trial of single versus multiple health behavior change: promoting physical activity and nutrition among adolescents. Health Psychology. 23(3), 314, 2004.

[23] Rahman S, Islam MT, Alam DS. Obesity and overweight in Bangladeshi children and adolescents: a scoping review. BMC public health. 14(1), 1-8, 2014.

[24] Reilly JJ, Kelly J. Long-term impact of overweight and obesity in childhood and adolescence on morbidity and premature mortality in adulthood: systematic review. International journal of obesity. 35(7), 891-8, 2011.

[25] Saraswathi YS, Najafi M, Gangadhar MR, Malini SS. Prevalence of childhood obesity in school children from rural and urban areas in Mysore, Karnataka, India. Journal of life sciences. 1; 3(1), 51-5, 2011.

[26] Shah P, Misra A, Gupta N, Hazra DK, Gupta R, Seth P, Agarwal A, Gupta AK, Jain A, Kulshreshta A, Hazra N. Improvement in nutrition-related knowledge and behaviour of urban Asian Indian school children: findings from the 'Medical education for children/Adolescents for Realistic prevention of obesity and diabetes and for healthy Geing'(MARG) intervention study. British Journal of Nutrition. 104(3), 427-36, 2010.

[27] Singhal N, Misra A, Shah P, Gulati S. Effects of controlled school-based multi-component model of nutrition and lifestyle interventions on behavior modification, anthropometry and metabolic risk profile of urban Asian Indian adolescents in North India. European journal of clinical nutrition. 64(4), 364-73, 2010.

[28] Sacher PM, Kolotourou M, Chadwick PM, Cole TJ, Lawson MS, Lucas A, Singhal A. Randomized controlled trial of the MEND program: a family - based community intervention for childhood obesity. Obesity. 18(S1), S62-8.2010.

[29] Snyder M. Self-monitoring processes. In Advances in experimental social psychology. Jan 1 (Vol. 12, pp. 85 128). Academic Press, 1979.

[30] Van Sluijs EM, McMinn AM, Griffin SJ. Effectiveness of interventions to promote physical activity in children and adolescents: systematic review of controlled trials. Bmj. 4; 335(7622), 703, 2007.

[31] Wang Y, Lobstein TI. Worldwide trends in childhood overweight and obesity. International journal of pediatric obesity. 1; 1(1), 11-25, 2006.

[32] Whincup PH, Gilg JA, Papacosta O, Seymour C, Miller GJ, Alberti KG, Cook DG. Early evidence of ethnic differences in cardiovascular risk: cross sectional comparison of British South Asian and white children. Bmj. 16; 324(7338), 635, 2002.

[33] World Health Organization. Global action plan for the prevention and control of noncommunicable diseases 2013 2020. 